\title{
Wastewater parameters after the process of phosphorus compounds removal by the metal dissolution method in comparison with precipitation and electrocoagulation methods
}

\author{
Parametry ścieków po procesie usuwania związków fosforu \\ metodą roztwarzania metali w porównaniu do metody strącania \\ solami metali i elektrokoagulacji
}

${ }^{*}$ Dr inż. Izabela Wysocka - University of Warmia and Mazury, Faculty

of Environmental Sciences, Department of Environmental Engineering,

Warszawska 117A St., 10-720 Olsztyn, e-mail: iwysocka@uwm.edu.pl

Keywords: dissolution of metals, precipitation, electrocoagulation, phosphorus compound removal, wastewater treatment

Słowa kluczowe: roztwarzanie metali, koagulacja, elektrokoagulacja, usuwanie związków fosforu, oczyszczanie ścieków

\begin{abstract}
Precipitation methods are commonly used for removing phosphorus compounds from wastewater. Chemical precipitation method, based on adding iron, aluminium or calcium salts to the treated wastewater, is often used. Another possible way of precipitating phosphates is metal dissolution method, which is presented in this paper. The main difference between these two methods is how the phosphate precipitating ions are introduced to the wastewater.

This paper discusses advantages and disadvantages of the metal dissolution method in comparison with traditional precipitation methods. Differences in the secondary contamination of treated wastewater by iron ions, conductivity, total alkalinity and $\mathrm{pH}$ correction process; the use of recyclable wastes; and energy consumption are discussed.
\end{abstract}

(C) IOŚ-PIB

\section{INTRODUCTION}

Increasing social awareness and strict legal regulations regarding the quality of discharged wastewater (the strategy 'end-of-pipe') have encouraged the development of new, more efficient methods of wastewater treatment. Following the strategy of 'clean production', the wastewater treatment processes should also adhere to the rules in force clean technologies.

During the wastewater treatment, there has been increased interest in the removal of biogenic phosphorus compounds that can be removed using precipitation methods. These methods include the metal dissolution method, electrocoagulation and conventional method of chemical precipitation.

The aim of this article is to show the differences between the metal dissolution method, electrocoagulation and conventional precipitation method (precipitation of metal salts) also in terms of the application 'clean production' strategy.

\section{Streszczenie}

Do efektywnych metod usuwania fosforu ze ścieków niewątpliwie należy zaliczyć metody strąceniowe. Najbardziej rozpowszechniona jest metoda strącania chemicznego bazująca na dozowaniu do roztworu soli żelaza, glinu lub wapnia. Na jej bazie powstała również proponowana w artykule metoda roztwarzania metali. Główną różnicą pomiędzy wymienionymi metodami jest sposób dozowania do roztworu środka strącającego.

Celem niniejszego artykułu jest ukazanie korzyści wynikających z zastosowania metody roztwarzania metali jak również skutków ubocznych, z którymi należy się liczyć. W artykule wskazuje się na zaistniałe różnice $\mathrm{w}$ problematyce związanej z wtórnym zanieczyszczeniem ścieków związkami żelaza, przewodniości, zasadowości i regulacji pH po procesie strącania chemicznego, jak również na takie aspekty, jak wykorzystanie surowców wtórnych czy nakłady energetyczne.

\section{THEORY}

Precipitation methods commonly use low solubility of iron phosphates (precipitation of phosphates) and phosphates sorption on the surface of produced precipitates. Subsequently, insoluble forms are being separated from the treated wastewater by flotation, sedimentation, filtration or combination of these methods. The total efficiency of the treatment is determined by the effectiveness of the separation of the precipitated compounds from the solution [Lattuada et al. 2003]. The resulting sludge (separated solids), together with other forms of sludge accumulated throughout the entire technological sequence of wastewater treatment, is subjected to further neutralisation processes, and the phosphate-free wastewater undergoes next stages of treatment. 
In traditional precipitation methods, metal ions are introduced to the solution byadding a coagulant[Buzzinietal. 2007]. Electrocoagulation is another way of introducing metal ions. In this method, metal ions can be released to the solution through electrolysis with the use of suitable reactive electrodes [Grøterud and Smoczyński 1992]. Removal of phosphorus compounds using metal dissolution, as proposed in the current paper, is a variant of the chemical precipitation method described in detail elsewhere [Wysocka and Giza 2011]. This method is based on similar premises as the electrocoagulation method; however, metal ions are introduced into the treated solution as a result of spontaneous corrosion process and, after further transformations in the wastewater environment, become responsible for the removal of phosphates.

The best results were observed under anaerobic conditions using steel fillings [Wysocka, and Krzemieniewski 2007]. Although using aluminium filling is possible, it requires considerable effort to remove the passivation layer of aluminium oxides present on the surface of the metal, complicating the treatment process [Chen 2004].

When steel is exposed to wastewater, the corrosion process became very intensive.

Iron corrosion in a solution deficient in oxygen produces iron ions in the form of $\mathrm{Fe}^{2+}$. As a result, metal reduction is observed on the anode (electrode corrosion) (Equation 1) [Wysocka et al. 2001].

Anode: $\quad \mathrm{Fe}_{\mathrm{m}} \rightarrow \mathrm{Fe}^{2+}+2 \mathrm{e}$

The rate of iron corrosion is usually determined by the rate of the much slower cathodic reaction (cathode control). Electrons from the anode migrate to the cathode. Hydrogen cations are reduced on the cathode and atomic hydrogen is created (Equation 2). If the $\mathrm{pH}$ of water is higher than 7 , hydrogen atoms combine into molecular forms (Equation 3) [Wysocka et al. 2001]. Cathode: $\begin{array}{rlrl}2 \mathrm{H}^{+}{ }_{\text {sol }}+2 \mathrm{e} & \rightarrow 2 \mathrm{H}_{\mathrm{a}} & \text { for } & \mathrm{pH}<7 \\ 2 \mathrm{H}^{+}{ }_{\text {sol }}+2 \mathrm{e} \rightarrow \mathrm{H}_{2 \mathrm{~g}} & \text { for } & \mathrm{pH}>7\end{array}$

(2) The specific electric conductivity was determined by a conductivity

(3) meter with automatic temperature correction (Conmet 2 HI 3292

$\mathrm{H}_{2} \mathrm{O} \rightarrow \mathrm{H}^{+}+\mathrm{OH}^{-}$

$\mathrm{Fe}^{2+}+2 \mathrm{OH}^{-} \rightarrow \mathrm{Fe}(\mathrm{OH})_{2 \downarrow}$

Generally, the anodic reaction can be presented as follows (Equation 6) [Lewandowski et al. 1997]:

$\mathrm{Fe}+2 \mathrm{H}_{2} \mathrm{O} \rightarrow \mathrm{Fe}(\mathrm{OH})_{2 \downarrow}+2 \mathrm{H}^{+}+2 \mathrm{e}$

In addition to the formation of hydroxides, other compounds (such as $\mathrm{Fe}_{3}\left(\mathrm{PO}_{4}\right)_{2}$ ) are also formed in wastewater. Similar to the process of coagulation and adsorption, it results in precipitation of residues containing phosphorus compounds.

In addition to electrochemical corrosion, the biological corrosion caused by a wide range of wastewater microorganisms is also very important, especially in wastewater conditions. This issue ATC Conductivity Probe, Hanna Instruments) and $\mathrm{pH}$ by a $\mathrm{pH}$ meter (Mikroprozessor-pH-meter HI9107, Hanna Instruments). The total alkalinity was determined by potentiometric titration. The iron content in the samples examined was determined with spectrophotometric method following measurement procedures

is quite complicated because of the large number of coexistent phenomena and further research of specific cases is required, taking into particular consideration the types of treated wastewater and the treatment processes.

\section{MATERIALS AND METHODS}

\subsection{Experimental setup}

The experiments were conducted under anaerobic conditions in reactors ( $5 \mathrm{~L}$ in capacity) with steel filling in the form of spiralshaped wires. The steel filling was made of steel wire (with a contact area of $0.54 \mathrm{~m}^{2}$ ), with a diameter of $2.2 \mathrm{~mm}$ and an iron content of $48 \%$.

In addition, to eliminate the effect of other factors (except filling) on the changes in the treated wastewater parameters, analysis of the wastewater after passing through the reactor without the filling was performed to establish a reference point.

During the experiment, synthetic wastewater was prepared on the basis of powdered milk $\left(\mathrm{P}_{\text {total }}=12 \mathrm{mg} \mathrm{P} \cdot \mathrm{L}^{-1}, \mathrm{PO}_{4}=7 \mathrm{mg} \mathrm{PO} \cdot \mathrm{L}^{-1}\right.$, $\mathrm{COD}=1,097 \mathrm{mg} \mathrm{O}_{2} \cdot \mathrm{L}^{-1}, \mathrm{BOD}_{5}=900 \mathrm{mg} \mathrm{O}_{2} \cdot \mathrm{L}^{-1}, \mathrm{~N}_{\text {total }}=61 \mathrm{mg} \mathrm{N} \cdot \mathrm{L}^{-1}$, specific electric conductivity $=0.89 \mathrm{mS} \cdot \mathrm{cm}^{-1}$, total alkalinity = $\left.9.8 \mathrm{mval} \cdot \mathrm{L}^{-1}, \mathrm{pH}=6.9\right)$ and beef stock $\left(\mathrm{P}_{\text {total }}=16 \mathrm{mg} \mathrm{P} \cdot \mathrm{L}^{-1}, \mathrm{PO}_{4}=\right.$ $12 \mathrm{mg} \mathrm{PO} \cdot \mathrm{L}^{-1}, \mathrm{COD}=1,057 \mathrm{mg} \mathrm{O}{ }_{2} \cdot \mathrm{L}^{-1}, \mathrm{BOD}_{5}=459 \mathrm{mg} \mathrm{O} \cdot \mathrm{L}^{-1}$, $\mathrm{N}_{\text {total }}=72 \mathrm{mg} \mathrm{N} \cdot \mathrm{L}^{-1}$, specific electric conductivity $=6.34 \mathrm{mS} \cdot \mathrm{cm}^{-1}$, $\mathrm{pH}=8.1$ ). The raw wastewater was analysed before introduction to the reactor. Hydraulic loading rate of the reactor from 0.5 to $3.2 \mathrm{~L} \cdot$ day $^{-1} \cdot \mathrm{L}^{-1}$ was used.

For analytical measurements, $0.5 \mathrm{~L}$ of wastewater samples were collected every three days and filtered through medium hardness filter paper. An analysis of the filtered liquid was performed.

\subsection{Analytical methods} provided by the manufacturer (the phenanthroline method). The arithmetic means were reported. The posed hypotheses used for the estimation of the differences between the particular elements were verified using analysis of variance or t-Student test. It was assumed that the differences were statistically significant at $p<0.05$.

\section{RESULTS AND DISCUSSION}

Precipitation methods, such as the conventional precipitation method (precipitation of metal salts), electrocoagulation and metal dissolution method $\left(\mathrm{Fe}^{0}\right)$, are effective methods of phosphorus compound removal. All of these methods are highly efficient in phosphate removal (exceeding 90\%) as well as in lowering the $\mathrm{COD}$ and $\mathrm{BOD}_{5}$ indicators and sulphur content in the treated wastewater [Buzzini et al. 2007]. 


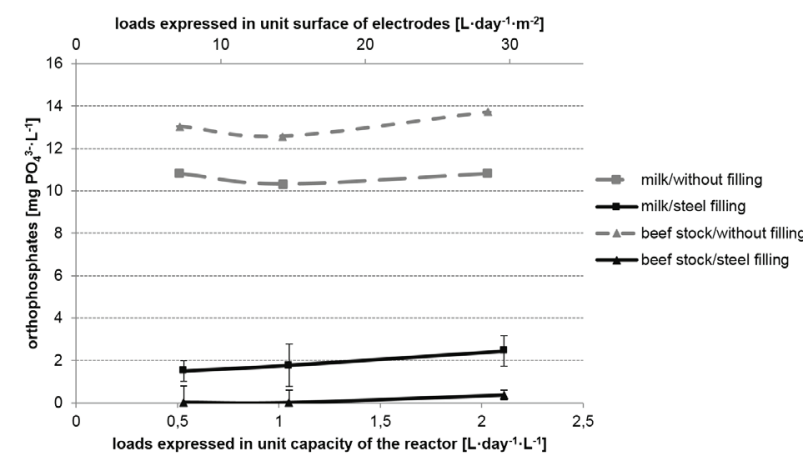

Figure 1. Orthophosphates of wastewater treated with the metal dissolution method.

Also the analysis demonstrated that the metal dissolution method resulted in a very high reduction in the concentration of orthophosphates, exceeding $90 \%$ (Fig. 1). In the current study, the orthophosphate removal efficiency ranged from $77 \%$ $\left(0.53 \mathrm{~L} \cdot \mathrm{d}^{-1} \cdot \mathrm{L}^{-1}\right)$ to $82 \%\left(1.05 \mathrm{~L} \cdot \mathrm{d}^{-1} \cdot \mathrm{L}-1\right)$ in the treated wastewater prepared on the basis of powdered milk. In the treated wastewater prepared on the basis of beef stock, the orthophosphate removal efficiency ranged from $97 \%\left(29.61 \mathrm{~L} \cdot \mathrm{d}^{-1} \cdot \mathrm{L}^{-1}\right)$ to $100 \%$ (0.53 L.d $\mathrm{d}^{-1} \cdot \mathrm{L}^{-1}$ and $\left.1.05 \mathrm{~L} \cdot \mathrm{d}^{-1} \cdot \mathrm{L}^{-1}\right)$ in practice. The subject, phosphorus removal, has been widely discussed in previous author's articles [Wysocka and Giza 2011, Wysocka and Krzemieniewski 2007, 2004, Wysocka et al. 2013, Wysocka 2013, Wysocka and Laduch 2012, Wysocka and Kościelniak 2011]. Despite a low initial concentration of orthophosphates in the treated wastewaters $\left(10.5 \mathrm{mg} \mathrm{P} \cdot \mathrm{L}^{-1}\right)$, at the final stage of the experiment, the wastewater exhibits very low concentration of orthophosphates - from 0.69 to $0.00 \mathrm{mg} \mathrm{P} \cdot \mathrm{L}^{-1}$. This indicates the feasibility of applying the metal dissolution method for the removal of even residual concentrations of orthophosphates from wastewaters [Wysocka et al. 2013]. However, this is a method that requires a slightly longer retention time (wastewater in contact with filling) than other precipitation methods. The orthophosphate removal efficiency of about $70 \%$ was obtained after 50 min of the electrocoagulation process $(I=0.7 \mathrm{~A}$, the surface of the electrodes is $\left.1,414 \mathrm{~cm}^{2}\right)$. A similar level of efficiency in metal dissolution method (corrosive surface electrodes $1414 \mathrm{~cm} 2$ ) was achieved after $180 \mathrm{~min}$. However, after $180 \mathrm{~min}$, the efficiency of metal dissolution method continued to increase (to $99 \%$ ), whilst electrocoagulation method managed to remove only $73 \%$ of orthophosphate [Wysocka and Giza 2011].

The method of applying the precipitating agent (i.e. metal ions) to the solution is the basic difference between the three methods. Whilst the conventional method of chemical precipitation requires a suitable preparation and dosage station of the coagulant and often additional aeration of the wastewater, the other two methods have lower requirements in these respects [Kobya et al. 2003].

The difference in energy consumption between the electrocoagulation process and the metal dissolution method is also significant. In the electrocoagulation process, the introduction of metal to the solution requires considerable energy expenditure [Buzzini et al. 2007]. The metal dissolution method, however, is based on spontaneous reaction and may significantly lower energy consumption, at least in the initial stage of wastewater treatment (which does not require energy expenditure). Another aspect in the case of metal dissolution method is the possibility of using recycled steel.

The precipitation methods remove the phosphorus compounds as a result of forming insoluble phosphate salts and by means of adsorption on the surface of the produced precipitate (iron and aluminium salts with phosphate ions or suitable hydroxides) [Smoczyński et al. 2007]. These mechanisms are responsible for phosphorus removal in conventional precipitation, electrocoagulation or metal dissolution methods. In addition, in the case of the metal dissolution method, an additional adsorptive surface of metal filling is present.

The most common is the chemical precipitation method that is based on applying iron, aluminium or calcium salt to the solution. In the classical method, the following are most often used as coagulants: iron (III) chloride (III), rarely iron (II) chloride, aluminium sulphate $(\mathrm{VI})$, sodium aluminate and calcium.

During the precipitation processes, as a result of anion exchange, sulphate or chloride ions stay in the solution, whilst phosphate ion is almost completely removed. As a result, the addition of coagulant results in secondary contamination of the wastewater. Both electrocoagulation and metal dissolution method are free from this problem [Irdemez et al. 2006c.]. Metal is dissolved into the solution as a result of spontaneous corrosion process. Iron ions are produced on one of the electrodes, whilst hydrogen is formed on the second electrode in its atomic or molecular form, depending on the $\mathrm{pH}$ reaction. However, in contrast to the conventional precipitation, the secondary contamination with sulphate or chloride ions should not be present [Buzzini et al. 2007].

The specific electric conductivity is determined by measuring the amount of ions dissolved in the solution. During the treatment carried out by Grøterud and Smoczyński [1992] with the electrocoagulation method, a decrease in specific electric conductivity from 4 to $30 \mathrm{mS} \cdot \mathrm{mL}^{-1}$ (depending on the process conditions) has been observed. And the research carried out by Benhadji et al. [2011] at first exhibited an increase from 2.3 to about $2.9 \mathrm{mS} \cdot \mathrm{mL}^{-1}$ and then a decrease of this parameter, practically $0 \mathrm{mS} \cdot \mathrm{mL}^{-1}$ (but it was aluminium electrode).

However, during the treatment carried out using the metal dissolution method, stable or slightly increased specific electric conductivity was observed (from 1.1 to $1.2 \mathrm{mS} \cdot \mathrm{mL}^{-1}$ for the synthetic wastewater prepared on the basis of powdered milk and 6.2 to $7.1 \mathrm{mS} \cdot \mathrm{mL}^{-1}$ for the synthetic wastewater prepared on the basis of beef stock), which confirmed the previous discussions (Fig. 2).

The final applicability of the coagulant is determined not only by the effectiveness of removal of the contaminant but also by the chemical stability of the medium after precipitation. If wastewater was used as a medium, the use of traditional coagulants influenced further stages of treatment. Total alkalinity has a large influence on the course of further treatment processes, particularly on the function of a biological treatment plant and the biocenosis of the natural ponds receiving treated wastewater. This indicates the ability to neutralise mineral acids. In the process of conventional chemical precipitation, aluminium or iron salts introduced to the solution undergoes hydrolysis and produces free inorganic 


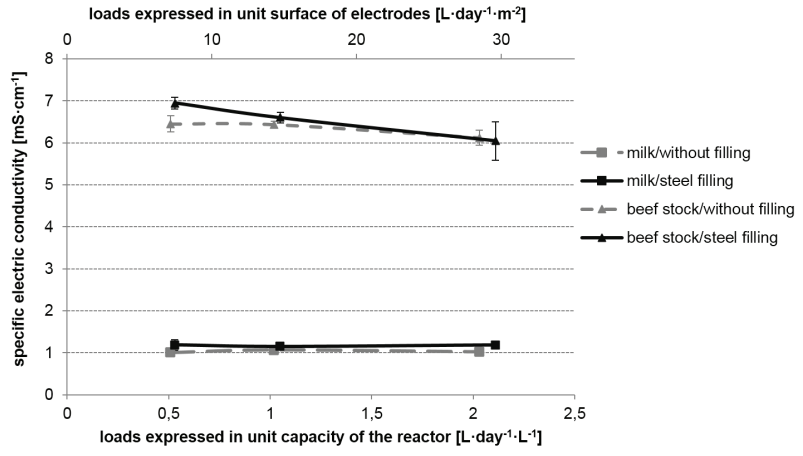

Figure 2. Specific electric conductivity of wastewater treated with the metal dissolution method.

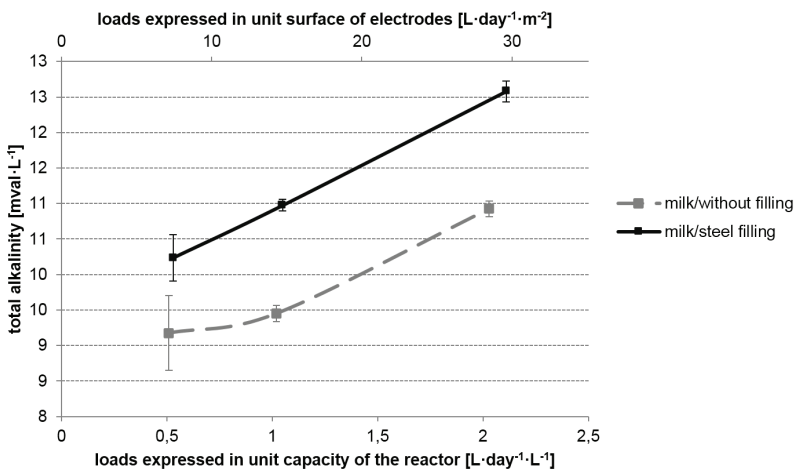

Figure 3. The total alkalinity of wastewater treated with the metal dissolution method.

acids. These acids reacted with the bicarbonates in the water environment. This resulted in a decrease in the amount of bicarbonates (total alkalinity) in the solution and an increase in free carbon dioxide content. This can cause the necessity of further intervention in the wastewater treatment process.

Use of the proposed method of metal dissolution (with steel fillings) ensured total alkalinity stability of the wastewater, and sometimes even a slight increase was observed (with 0.10$6.6 \mathrm{mval} \cdot \mathrm{L}^{-1}$ - comparison of the results from the wastewater after passing through the reactor without the filling). In the current study, it ranged from 10.00 to $15.60 \mathrm{mval} \cdot \mathrm{L}^{-1}$ in the treated wastewater prepared on the basis of powdered milk (Fig. 3). No chloride or sulphate ions were introduced into the solution, which may explain the results.

Conventional precipitation methods also often required performing a correction of the $\mathrm{pH}$ because of the changes caused by the introduction of sulphate or chloride salts [Buzzini et al. 2007]. According to Kobya et al. [2007], with the same initial pH, the final $\mathrm{pH}$ is 7.9 in electrocoagulation but 2.9 in conventional precipitation $\left(\mathrm{FeCl}_{2}\right)$. But there are numerous factors that determine the $\mathrm{pH}$ change required and should be considered every time given problem individually.

During the corrosion processes that release metal ions to the solution, no significant so large changes of $\mathrm{pH}$ reaction, as in the case of conventional precipitation, were observed. In the current study, the solution averaged between 7.0 and $8.7 \mathrm{pH}$ (Fig. 4), which significantly simplified the treatment process.

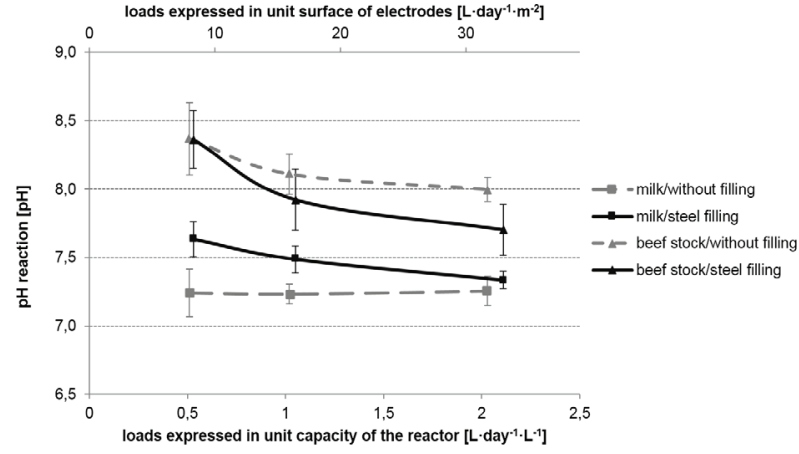

Figure 4. The $\mathrm{pH}$ of wastewater treated with the metal dissolution method.

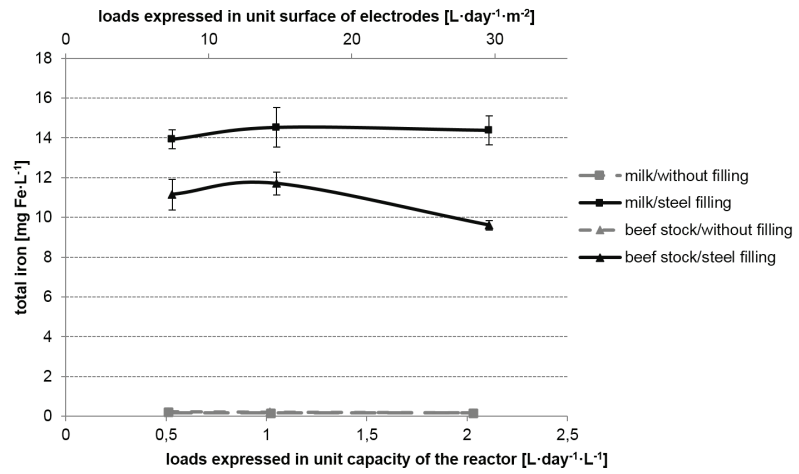

Figure 5. The total iron in wastewater treated with the metal dissolution method.

Unfortunately, introduction of metal ions to wastewater in order to remove phosphates resulted in secondary contamination with excess iron ions during the metal dissolution process, which reached levels of $6.2-16.0 \mathrm{mg} \mathrm{Fe} \cdot \mathrm{L}^{-1}$ (Fig. 5) in the treated solution. In the case of the electrocoagulation, in research carried out by Wysocka and Laduch [2012] using the synthetic wastewater, concentrations were even less and between 1.8 and $42.7 \mathrm{mg} \mathrm{Fe} \cdot \mathrm{L}^{-1}$, depending on the process duration. In the case of conventional precipitation as reported Liang et al. [2009], it reached levels up to $230 \mathrm{mg} \mathrm{Fe} \cdot \mathrm{L}^{-1}$ depending on the $\mathrm{pH}$ of the treated wastewater and coagulant dose. As shown, this was a problem that affected both the conventional method of phosphate precipitation and the electrocoagulation and metal dissolution methods [Wysocka, and Krzemieniewski 2007].

Iron compounds may occur in both dissolved and colloidal forms in the treated wastewater. The higher the solubility of the iron compounds, the larger was the amount of ions remaining in the solution.

The problem of the presence of dissolved iron forms was more pronounced for the conventional method than for electrocoagulation or metal dissolution methods because of the increased presence of sulphate or chloride ions, which produced soluble salts of those metals. However, the colloidal forms posed the same problem in each method [Buzzini et al. 2007], thus indicating that further treatment would be necessary to reduce iron concentration. More research is needed to better understand how to limit this phenomenon. One method may be the oxidation 
processes. The processes of wastewater oxidation are commonly used in numerous treatment plants, so there should not be any bigger investment or an exploitation problem. Removal of the iron compounds using the oxidation processes is a commonly used practice in water treatment plants.

The examinations carried out on the wastewater treated with the metal dissolution methods point [Wysocka 2009] to a high efficiency of oxidation processes in decreasing the negative influence of the secondary wastewater contamination with the compounds of soluble metals, and at the same time, they do not indicate any reductions in the efficiency of phosphorus compound removal - they even slightly improve the final effect of removing the phosphorus from the wastewater.

Control of the speed of the corrosion processes may become the greatest disadvantage of the metal dissolution method. The amount of iron present in the wastewater after the phosphorus removal process using the metal dissolution method was a function of the corrosion process. The more effective the process was, the greater was the amount of ions introduced into the solution. Thus, it became crucial to control the corrosion of the filling so that excessive release of iron ions to the solution could be avoided.

Preliminary research indicated the possibility of controlling the speed of corrosion processes by introducing other metals to the filling. The standard potential of such metals should be higher than the potential of the metal that is to be dissolved to slow down the corrosion processes [Wysocka and Krzemieniewski 2004].

Other parameters (e.g. reaction type, the presence of oxygen, chlorides or other ions in the wastewater, as well as the presence of microorganisms) may also be used to control the process of secondary wastewater contamination with iron compounds [Irdemez et al. 2006a, 2006b]. Although the issue is very interesting, it is also very complicated. Thus, it requires a separate study and more specialised research to consider the types of treated wastewater and the conditions of the treatment process.

In conventional chemical precipitation and electrocoagulation processes, it is possible to use aluminium (aluminium coagulants or aluminium electrodes) [Mollah et al. 2001]. The experiments conducted for the iron dissolution method found that removing phosphorus compounds with this method exhibits positive effects only in cases where steel was present in the filling, although the aluminium did not corrode to a satisfactory level [Wysocka and Krzemieniewski 2007]. The corrosion of aluminium is probably hindered by the passivation layer of aluminium oxides on the surface. Conducting a process of removal of phosphorus from the wastewater with the use of aluminium required conditions that can remove the passivation layer, for example, by mixing the aluminium filling with a metal of a much higher standard potential or the presence of ions or microorganisms in the wastewater, which were capable of decomposing the layer of oxide. In this case, removing phosphorus using aluminium was more complicated. In addition, the price of aluminium is much higher than that of iron, which often disqualifies it.

Applying the metal dissolution method made it possible to reuse the waste scrap metal, which is an environmentally friendly option. It is an additional aspect that should be considered when choosing the phosphorus compound removal method.

\section{CONCLUSION}

Physical and chemical methods for the removal of phosphorus compounds are highly effective (phosphorus removal often reaches $90 \%$ ) and relatively simple to use. The method of chemical precipitation based on introducing iron, aluminium or calcium salts to the solution is the most common. This method has been modified in numerous ways. In line with the strategy of 'clean production', based on these modifications, other methods, such as electrocoagulation and the metal dissolution method proposed by the author, have been developed. The main difference between these methods lies in the way of introducing the precipitation agent (e.g. a metal that produces oxides, hydroxides or precipitating salts) to the solution [Chen 2004]. The latter determines the advantages and disadvantages of the particular methods.

The electrocoagulation and metal dissolution methods were characterised by a lack of increase in wastewater salinity that occurred in the traditional precipitation method.

After the treatment, an increase in the concentration of sulphates and chlorides was not observed. During the experiments carried out using the metal dissolution method, stability or a slight decrease in specific electric conductivity was observed $\left(0.7 \mathrm{mS} \cdot \mathrm{mL}^{-1}\right)$.

The introduction of sulphates or chlorides to the solution (in the conventional precipitation method) also contributed to the decrease in the acid capacity of the wastewater. It was a significant disadvantage of the process. This impeded the further stages of wastewater treatment using biological methods and had a negative effect on the biocenosis of a natural receiving pond. Application of the proposed method of metal dissolution (with steel filling) ensured total alkalinity stability of the wastewater and sometimes even a slight increase in this parameter was observed (with 0.10-6.6 mval $\cdot \mathrm{L}^{-1}$ ). This was undoubtedly an advantage of this method.

Another advantage of electrocoagulation and metal dissolution methods was the lack of necessity of correction of the $\mathrm{pH}$, which averaged between 7.0 and $8.7 \mathrm{pH}$. This was of great importance for the further wastewater treatment processes, particularly if they were conducted with the use of microorganisms.

Secondary wastewater contamination with iron, aluminium or calcium compounds was a fundamental problem in all precipitation methods. This problem was also present when the metal dissolution method was used. During the metal dissolution method, the iron level in treated wastewater ranged between 6.2 and $16.0 \mathrm{mg} \mathrm{Fe} \cdot \mathrm{L}^{-1}$. More research is needed into how to limit this phenomenon. However, the metal dissolution method was undoubtedly disadvantageous because of the difficulty in controlling the metal dosing to the solution and requires more research.

Other obvious advantage of the metal dissolution method was the ability of reusing recyclable metal waste according to the current trends, as well as lower energy expenditures (in contrast to electrocoagulation processes). 


\section{REFERENCES}

BENHADJI A., AHMED M., MAACHI R. 2011. Electrocoagulation and effect of cathode materials on the removal of pollutants from tannery wastewater of Rouiba. Desalination 277: 128134.

BUZZINI A., PATRIZZI L., MOTHEO A., PIRES E. 2007. Preliminary evaluation of the electrochemical and chemical coagulation processes in the post-treatment of effluent from an upflow anaerobic sludge blanket (UASB) reactor. Journal of Environmental Management 85: 847-857.

CHEN G. 2004. Electrochemical technologies in wastewater treatment. Separation and Purification Technology 38: 11-41.

GRØTERUD O., SMOCZYŃSKI L. 1992. Purification of wastewater by electrolysis at continuous flow. Vatten 48: 3640.

IRDEMEZ S., DEMIRCIOGLU N., YILDIZ Y. 2006a. The effects of $\mathrm{pH}$ on phosphate removal from wastewater by electrocoagulation with iron plate electrodes. Journal of Hazardous Materials 137: 1231-1235.

IRDEMEZ S., DEMIRCIOGLU N., YIDIZ Y., BINGUL Z. 2006b. The effects of current density and phosphate concentration on phosphate removal from wastewater by electrocoagulation using aluminum and iron plate electrodes. Separation and Purification Technology 52: 218-223.

IRDEMEZ S., YILDIZ Y., TOSUNOGLU V. 2006c. Optimization of phosphate removal from wastewater by electrocoagulation with aluminum plate electrodes. Separation and Purification Technology 52: 394-401.

KOBYA M., BAYRAMOGLU M., EYVAZ M. 2007. Technoeconomical evaluation of electrocoagulation for the textile wastewater using different electrode connections. Journal of Hazardous Materials 148: 311-318.

KOBYA M., CAN O., BAYRAMOGLU M. 2003. Treatment of textile wastewaters by electrocoagulation using iron and aluminum electrodes. Journal of Hazardous Materials 100: 163-178.

LATTUADA M., WU H., MORBIDELLI M. 2003. A simple model for the structure of fractal aggregates. Journal of Colloid and Interface Science 268: 106-120.

LEWANDOWSKI Z., DICKINSON W., LEE W. 1997. Electrochemical interactions of biofilms with metal surfaces. Water Science and Technology 36: 295-302.

LIANG Z., WANG Y., ZHOU Y., LIU H. 2009. Coagulation removal of melanoidins from biologically treated molasses wastewater using ferric chloride. Chemical Engineering Journal 152: 8894.
MOLLAH M., SCHENNACH R., PARGA J. COCKE D. 2001. Electrocoagulation (EC) - science and applications. Journal of Hazardous Materials 84: 29-41.

SMOCZYŃSKI L., WARDZYŃSKA R., ZAŁĘSKA-CHRÓST B., BUKOWSKI Z. 2007. Computer simulation of latent coagulation. Polish Journal of Natural Sciences 22, 1: 73-82.

WYSOCKA I. 2009. The problem of secondary contamination of sewage with iron compounds during the process of sewage treatment with the method of metal dissolution. Polish Journal of Environmental Studies, Series of Monographs 4: 81-84.

WYSOCKA I. 2013. A Comparative Study of Metals Solubilization and Electrocoagulation Methods' Effectiveness in Orthophosphate Removal from Synthetic Wastewater. Polish Journal of Environmental Studies 22, 3: 945-949.

WYSOCKA I., GIZA M. 2011. Comparison of the Results of Orthophosphates Removal from Sewage Using Electrocoagulation Method and Metal Digestion Method. Rocznik Ochrona Środowiska 13: 1915-1925. [in Polish].

WYSOCKA I., KISIELEWSKA M., RYNKIEWICZ, M., KONOPKA S. 2013. Orthophosphates Removal from Synthetic Neutral and Alkaline Wastewater Using the Electrocoagulation and the Metal Dissolution Methods. Rocznik Ochrona Środowiska 15: 2725-2737. [in Polish].

WYSOCKA I., KOŚCIELNIAK T. 2011 Wpływ napowietrzania na efektywność usuwania fosforu ze ścieków metodą roztwarzania metali, Inżynieria Ekologiczna 24:154-163.

WYSOCKA I., KRZEMIENIEWSKI M. 2004. Effect of phosphorus removal with the method of metal solubilisation on the quality of treated wastewater (Przemiany zanieczyszczeń ścieków w reaktorze z wypełnieniem stalowym i aluminiowym). Ochrona Środowiska 26, 4: 31-36. [in Polish].

WYSOCKA I., KRZEMIENIEWSKI M. 2007. The effects of total phosphorus and orthophosphates removal with the method of metals solubilisation on steel, aluminum, and mixed media. Polish Journal of Natural Sciences 22, 4: 307-316.

WYSOCKA I., KRZEMIENIEWSKI M., JANCZUKOWICZ W., PESTA, J. 2001. Influence of metal ions introduction to the solution by corrosion, on phosphorus removal from wastewater. Natural Sciences 9: 307-316.

WYSOCKAI., LADUCH W. 2012. Orthophosphates Removal from Synthetic Sewage with Low pH Using the Electrocoagulation and the Metal Digestion Method. Rocznik Ochrona Środowiska 14: 790-799. [in Polish]. 